\title{
The effect of wheat bran on the absorption of minerals in the small intestine
}

\author{
BY ANN-SOFIE SANDBERG, CLAES HASSELBLAD \\ AND KRISTINA HASSELBLAD \\ Department of Clinical Nutrition, Sahlgren's Hospital, Gothenburg, Sweden \\ AND LEIF HULTÉN \\ Department of Surgery II, Sahlgren's Hospital, Gothenburg, Sweden
}

(Received 3 September 1981-Accepted 15 February 1982)

\begin{abstract}
1. Studies on mineral absorption were carried out in ileostomy patients using the metabolic balance technique. The effect of wheat bran on the absorption of phosphorus, calcium, magnesium, zinc and iron was studied. The extent of digestion of bran phytate in the stomach and small intestine was also investigated.

2. Eight patients with well established conventional ileostomies were studied during two periods while on a constant low-fibre diet. In the second period, $16 \mathrm{~g}$ wheat bran/d (American Association of Cereal Chemists) was added to the diet. The amount of phytate-P, non-phytate-P, $\mathrm{Ca}, \mathrm{Mg}, \mathrm{Zn}$ and $\mathrm{Fe}$ was determined in the ileostomy contents and in duplicate portions of the diet.

3. Of the added bran phytate-P $24-61 \%$ was recovered in the ileostomy contents. In the bran period a significantly decreased amount of $\mathrm{Zn}$ was absorbed, while the apparent absorption of $\mathrm{Fe}$ and phytate-P increased and that of non-phytate-P, $\mathrm{Ca}$ and $\mathrm{Mg}$ remained constant. Due to the mineral content of bran, the relative absorption differed in some respects from the absolute absorption, being decreased for $\mathrm{Zn}, \mathrm{Mg}$ and phytate-P but unchanged for $\mathrm{Ca}, \mathrm{Fe}$ and non-phytate-P.

4. It is concluded that phytate is partly digested in the stomach and small intestine or possibly absorbed. Addition of $16 \mathrm{~g}$ bran/d to the diet does not seem to impair the mineral absorption from the small intestine except that of $\mathrm{Zn}$.
\end{abstract}

Wheat bran has been suggested as having an inhibitory effect on mineral absorption (McCance \& Widdowson, 1942a, b; Ismail-Beige et al. 1977; Cummings, 1978; Davies, 1979). The supposed impairment of mineral absorption is ascribed to the high content of phytate or fibre in bran; components which have a capacity to bind metals in vitro. Studies on zinc and iron absorption, both those utilizing the radionucleide technique (BjörnRasmussen, 1974; Dobbs \& Baird, 1977; Simpson et al. 1981; B. Sandström, unpublished results) and those performed with conventional metabolic-balance technique (McCance \& Widdowson, 1942a, $b$; Reinhold et al. 1973, 1976a, b) have pointed in that direction. However, the studies measuring the uptake of radioactive $\mathrm{Fe}$ and $\mathrm{Zn}$ isotopes have been carried out as single-meal tests and it does not give a measure of the total absorption from all the meals during the day. The metabolic-balance technique has serious limitations as regards trace elements since even a minor contamination may affect the results since the level of absorption usually is relatively low (Sandström, 1980). Small analytical errors and practical problems in demarcating faeces in portions that correspond to the period of intake can cause large errors in the final evaluation of the calculated absorption (Isaksson \& Sjögren, 1967).

The fate of ingested phytin-phosphorus in the human body has been investigated by McCance \& Widdowson (1935), who concluded that $20-60 \%$ is excreted unchanged in the faeces. Whether or not digestion and absorption of phytate from bran occurs in the stomach and small intestine or colon is unknown.

The aim of the present investigation was to study the effect of wheat bran on the absorption of $\mathrm{Fe}, \mathrm{Zn}$, magnesium, calcium and $\mathrm{P}$. To avoid the practical problems and errors 
associated with collecting and demarcating faeces the study was confined to well established conventional ileostomy patients. Balance studies in this group of patients, collecting the ileostomy contents in external appliances, would be greatly facilitated and would also allow for an estimation to what extent phytate in bran is digested in the stomach and small intestine.

The Ethical Committee of Sahlgren's Hospital approved the study.

\section{SUBJECTS AND METHODS}

Subjects. Eight patients (six men, mean age 38 years; two women aged 52 and 67 years) 7 months to 2 years previously proctocolectomized for ulcerative colitis and with wellestablished ileostomies volunteered to take part in the study. Only a few centimetres of the terminal ileum had been removed. The ileostomies functioned properly and the volumes of excreta were within normal range without the use of drugs. The patients were hospitalized for local treatment of persisting perineal sinuses but were otherwise healthy and in excellent general condition, having completely recovered after surgery. General drug therapy was given only to one patient who took Seloken (Hässle, $\beta$-adrenergic receptor antagonist).

Experimental model. Five patients were studied for two consecutive weeks at hospital. In the first week (period 1), starting on Monday at lunch and ending on Friday morning after breakfast, the patients were given a constant low-fibre diet. They spent the weekend at home. The next week (period 2) the same regimen was followed except that the constant low-fibre diet was now supplemented with $16 \mathrm{~g}$ wheat bran/d. The other three patients were studied during ten consecutive days on a low-fibre diet supplemented with bran on days 5,6 and 7 .

Diets. The low-fibre diet consisted mainly of rice, fish or meat, white bread and ice-cream.

American Association of Cereal Chemists (AACC) certified food grade wheat bran was used in the study, except for patient no. 1, who was given a Swedish commercial bran. In period 2, $16 \mathrm{~g}$ raw bran was taken in separate doses during the day, mixed in rice (lunch, dinner) or on the sandwiches.

Duplicate portions of the diet were collected on the third day in each period and homogenized. Minerals and phytate-P were analysed in diets, and bran was analysed separately. Details of diets, collection and analytical methods for determination of fibre components and starch have been given elsewhere (Sandberg et al. 1981).

Collection of ileostomy contents. Ileostomy contents were collected the last $3 \mathrm{~d}$ in each period. For patients studied during $10 \mathrm{~d}$, ileostomy contents were collected during the last $9 \mathrm{~d}$.

Analytical methods. The ileostomy contents of each $24 \mathrm{~h}$ period and duplicate portions of diet were analysed. All mineral and phytate-P analyses were performed in acid-washed glassware and only demineralized water was used in analyses. Duplicate samples for analyses of $\mathrm{Fe}, \mathrm{Zn}$ and $\mathrm{Mg}$ were prepared by dry-ashing of freeze-dried material $(0.3 \mathrm{~g}$ ileostomy contents or $0.6 \mathrm{~g} \mathrm{diet}$ ) at $450^{\circ}$ overnight. After cooling, three drops of nitric acid $(2: 1, v / v)$ were added, the ashing was continued, another three drops of $\mathrm{HNO}_{3}$ were added and then ashing continued until a white or yellow residue remained. The ash was dissolved in $5 \mathrm{ml} 5 \mathrm{M}$-hydrochloric acid and allowed to stand under cover overnight. The solutions were transferred with demineralized water to $25 \mathrm{ml}$ flasks (diet samples) and $100 \mathrm{ml}$ flasks (ileostomy contents) respectively and made to volume. Triple samples for $\mathrm{Ca}$ and $\mathrm{P}$ analyses were prepared by the wet-ashing of $0.1 \mathrm{~g}$ freeze-dried material in $1 \mathrm{ml}$ sulphuric acid and $3 \mathrm{ml}$ hydrogen peroxide for $15 \mathrm{~min}$ at $295^{\circ}$. (If the digest was not colourless the ashing was continued after adding another $2 \mathrm{ml} \mathrm{H}_{2} \mathrm{O}_{2}$.) The digests were diluted with demineralized water to $75 \mathrm{ml}$.

$\mathrm{Fe}, \mathrm{Zn}, \mathrm{Mg}$ and $\mathrm{Ca}$ were determined against their blanks in an atomic absorption 
Table 1. Intake, recovery in ileostomy fuid, and apparent absorption of phytate-P and non-phytate-P

(Mean values with their standard errors)

\begin{tabular}{|c|c|c|c|c|}
\hline & \multicolumn{2}{|c|}{$\begin{array}{l}\text { Phytate-P } \\
(\mathrm{mmol} / 24 \mathrm{~h})\end{array}$} & \multicolumn{2}{|c|}{$\begin{array}{c}\text { Non-phytate-P } \\
(\mathrm{mmol} / 24 \mathrm{~h})\end{array}$} \\
\hline & Mean & $\mathbf{S E}$ & Mean & SE \\
\hline $\begin{array}{l}\text { Intake: } \\
\text { Diet } \\
\text { Swedish bran } \\
\text { AACC }^{*} \text { bran }\end{array}$ & $\begin{array}{l}1.2 \\
4.2 \\
3.9\end{array}$ & $\begin{array}{c}0.14 \\
- \\
-\end{array}$ & $\begin{array}{r}48.4 \\
2.0 \\
1.7\end{array}$ & $\frac{3 \cdot 3}{-}$ \\
\hline $\begin{array}{l}\text { Recovery in ileostomy fluid: } \\
\text { Period } 1 \dagger \\
\text { Period } 2 \dagger \\
\text { Period } 3 \ddagger \\
\text { Statistical significance of } \\
\text { difference between periods } 1 \text { and } 2(P)\end{array}$ & $\begin{aligned} & 0.29 \\
& 1.9 \\
& 0.28 \\
&< 0.01\end{aligned}$ & $\begin{array}{l}0.03 \\
0.16 \\
0.03 \\
-\end{array}$ & $\begin{array}{r}12 \cdot 8 \\
15 \cdot 5 \\
15 \cdot 2 \\
\text { NS }\end{array}$ & $\begin{array}{r}2 \cdot 1 \\
2 \cdot 7 \\
4 \cdot 7 \\
-\end{array}$ \\
\hline $\begin{array}{l}\text { Amounts absorbed: } \\
\text { Period } 1 \\
\text { Period } 2 \\
\text { Period } 3 \\
\text { Statistical significance of } \\
\text { difference between periods } 1 \text { and } 2(P)\end{array}$ & $\begin{array}{c}0.88 \\
3.22 \\
1.20 \\
<0.01\end{array}$ & $\begin{array}{l}0.13 \\
0.29 \\
0.19 \\
-\end{array}$ & $\begin{array}{r}35 \cdot 5 \\
34 \cdot 6 \\
32 \cdot 5 \\
\text { NS }\end{array}$ & $\begin{array}{l}2 \cdot 1 \\
2 \cdot 3 \\
3 \cdot 0 \\
-\end{array}$ \\
\hline $\begin{array}{l}\text { Relative absorption: } \\
\text { Period } 1 \\
\text { Period } 2 \\
\text { Period } 3 \\
\text { Statistical significance of } \\
\text { difference between periods } 1 \text { and } 2(P)\end{array}$ & $\begin{array}{r}0.74 \\
0.62 \\
0.80 \\
<0.02\end{array}$ & $\begin{array}{c}0.03 \\
0.04 \\
0.05 \\
-\end{array}$ & $\begin{array}{l}0.74 \\
0.69 \\
0.69 \\
\text { NS }\end{array}$ & $\begin{array}{c}0.03 \\
0.04 \\
0.04 \\
-\end{array}$ \\
\hline
\end{tabular}

- American Association of Cereal Chemists.

+ Mean values of $3 \mathrm{~d}$ collection of ileostomy contents when the subjects were given a constant low-fibre diet (period 1) or a diet supplemented with $16 \mathrm{~g}$ wheat bran/d (period 2).

$\ddagger$ For the three patients studied during ten consecutive days; mean values of the last $3 \mathrm{~d}$ collection of ileostomy contents when the subjects took a constant low-fibre diet.

spectrophotometer (Perkin Elmer Model 360). P was determined by a colorimetric method according to Fiske \& Subbarow (1925).

Phytate was determined by an Fe-precipitation method according to Ellis et al. (1977) modified by Hasselblad \& Sandberg (unpublished results) and analysis of phytate-P. Samples of $0.5 \mathrm{~g}$ freeze-dried diet or ileostomy contents were extracted with $20 \mathrm{ml} 0.5 \mathrm{M}-\mathrm{HCl}$ containing sodium sulphate $(50 \mathrm{~g} / \mathrm{l})$, filtrated through a Munktell $\mathrm{OOH}$ filter, frozen overnight and filtrated through an MF-Millipore filter $(0 \cdot 10 \mu \mathrm{m}$ pore size) under pressure. Each sample was then precipitated with ferric ion by adding $0.25 \mathrm{ml}$ ferric chloride $(4 \mathrm{~g} / \mathrm{l})$ in $0.5 \mathrm{M}-\mathrm{HCl}$ containing $\mathrm{Na}_{2} \mathrm{SO}_{4}(50 \mathrm{~g} / \mathrm{l})$ to $5 \mathrm{ml}$ of the filtrate. The mixtures were kept in a $95^{\circ}$ water-bath for $20 \mathrm{~min}$, cooled and centrifuged at $2300 \mathrm{rev}$. $/ \mathrm{min}$ for $20 \mathrm{~min}$ at $20^{\circ}$. The ferric precipitates were washed three times with $5 \mathrm{ml} 0.5 \mathrm{M}-\mathrm{HCl}$ and then dissolved in $1 \mathrm{ml}$ concentrated $\mathrm{H}_{2} \mathrm{SO}_{4}$. From each tube was withdrawn $0.75 \mathrm{ml}$ for wet-ashing at $295^{\circ}$ for $15 \mathrm{~min}, \mathbf{0 . 2 5} \mathrm{ml} \mathrm{H}_{2} \mathrm{O}_{2}(300 \mathrm{ml} / \mathrm{l})$ was added, and then the wet-ashing was continued for another $15 \mathrm{~min}$. The digests were quantitatively transferred to $10 \mathrm{ml}$ flasks, diluted with approximately $8 \mathrm{ml}$ demineralized water, kept in a boiling water-bath for $15 \mathrm{~min}$, then cooled and made up to volume. The flasks were allowed to stand at room temperature overnight and then analysed for P according to Fiske \& Subbarow (1925). Addition of calcium hydrogen phosphate to samples of diets and ileostomy contents verified that no coprecipitation of inorganic phosphate occurred when phytate was precipitated with $\mathrm{Fe}^{3+}$ as described previously. 
Table 2. Intake, recoveries in ileostomy fluid, and 'apparent absorption' of minerals (Mean values with their standard errors)

\begin{tabular}{|c|c|c|c|c|c|c|c|c|}
\hline & \multicolumn{2}{|c|}{$\underset{(\mathrm{mmol} / 24 \mathrm{~h})}{\text { Calcium }}$} & \multicolumn{2}{|c|}{$\underset{(\mathrm{mmol} / 24 \mathrm{~h})}{\text { Magnesium }}$} & \multicolumn{2}{|c|}{$\underset{(\mathrm{mg} / 24 \mathrm{~h})}{\text { Zinc }}$} & \multicolumn{2}{|c|}{$\underset{(\mathrm{mg} / 24 \mathrm{~h})}{\text { Iron }}$} \\
\hline & Mean & $\mathrm{SE}$ & Mean & $\mathbf{S E}$ & Mean & $\mathbf{S E}$ & Mean & SE \\
\hline \multicolumn{9}{|l|}{ Intake: } \\
\hline Diet & $31 \cdot 8$ & $2 \cdot 6$ & $9 \cdot 0$ & 0.5 & $12 \cdot 9$ & $1 \cdot 2$ & $10 \cdot 6$ & 0.9 \\
\hline Swedish bran & $0-57$ & - & $2 \cdot 8$ & - & $1 \cdot 0$ & - & 1.7 & - \\
\hline AACC ${ }^{*}$ bran & $0 \cdot 60$ & - & $3 \cdot 0$ & - & $1 \cdot 3$ & - & $2 \cdot 2$ & - \\
\hline \multicolumn{9}{|l|}{ Recovery in ileostomy fluid: } \\
\hline Period $1 \dagger$ & $19 \cdot 6$ & 1.8 & $5 \cdot 0$ & $0 \cdot 31$ & $10 \cdot 9$ & $1 \cdot 2$ & $8 \cdot 2$ & 0.74 \\
\hline Period $2 \dagger$ & $21 \cdot 7$ & $2 \cdot 3$ & $7 \cdot 3$ & 0.36 & 12.7 & $1 \cdot 2$ & $9 \cdot 1$ & 0.61 \\
\hline Period $3 \ddagger$ & $19 \cdot 0$ & $2 \cdot 7$ & $4 \cdot 8$ & 0.44 & $10 \cdot 4$ & 1.6 & 7.6 & 0.46 \\
\hline $\begin{array}{l}\text { Statistical significance } \\
\text { of difference between } \\
\text { periods } 1 \text { and } 2(P)\end{array}$ & $<0.02$ & - & $<0.01$ & - & $<0.01$ & - & $<0.01$ & - \\
\hline \multicolumn{9}{|l|}{ Amounts absorbed: } \\
\hline Period 1 & $12 \cdot 2$ & $1 \cdot 5$ & $4 \cdot 1$ & 0.34 & $2 \cdot 0$ & $0 \cdot 30$ & $2 \cdot 5$ & 0.37 \\
\hline Period 2 & $10 \cdot 8$ & $1 \cdot 3$ & $4 \cdot 5$ & 0.39 & $1 \cdot 2$ & $0 \cdot 31$ & $3 \cdot 3$ & 0.44 \\
\hline Period 3 & $15 \cdot 2$ & $3 \cdot 3$ & $4 \cdot 0$ & $0 \cdot 10$ & 1.9 & 0.64 & $2 \cdot 2$ & 0.23 \\
\hline $\begin{array}{l}\text { Statistical significance } \\
\text { of difference between } \\
\text { periods } 1 \text { and } 2(P)\end{array}$ & NS & - & NS & - & $<0.01$ & - & $<0.02$ & - \\
\hline \multicolumn{9}{|l|}{ Relative absorption: } \\
\hline Period 1 & $0 \cdot 38$ & 0.029 & 0.45 & 0.025 & $0 \cdot 16$ & 0.023 & 0.23 & 0.032 \\
\hline Period 2 & 0.34 & 0.034 & 0.38 & 0.025 & 0.076 & 0.020 & 0.26 & 0.031 \\
\hline Period 3 & 0.44 & 0.029 & 0.45 & 0.028 & 0.16 & 0.066 & 0.23 & 0.021 \\
\hline $\begin{array}{l}\text { Statistical significance } \\
\text { of difference between } \\
\text { periods } 1 \text { and } 2(P)\end{array}$ & NS & - & $<0.01$ & - & $<0.01$ & - & NS & - \\
\hline
\end{tabular}

* American Association of Cereal Chemists.

$\uparrow$ Mean values of $3 \mathrm{~d}$ collection of ileostomy contents when the subjects were given a constant low-fibre diet (period 1) or a low-fibre diet supplemented with $16 \mathrm{~g}$ wheat bran/d (period 2).

$\ddagger$ For the three patients studied during ten consecutive days; mean values of the last $3 \mathrm{~d}$ collection of ileostomy contents when the subjects took a constant low-fibre diet.

Calculations and statistical methods. The amount of undigested bran phytate was estimated as the difference between analytical values of ileostomy contents of periods 1 and 2 for each patient. The value for non-phytate-P was calculated as the difference between total phosphorus and phytate-P and apparent absorption of minerals as the difference between dietary intake and recovery in ileostomy contents. For statistical comparison of values from the two periods Wilcoxon's matched-pairs signed-ranks test was used.

\section{RESULTS}

Recovery of unabsorbed phytate-P and non-phytate $P$ in the ileostomy contents. Daily intake of phytate-P and non-phytate-P from the low-fibre diet and bran and recovery in ileostomy contents are summarized in Table 1. Phytate-P constituted only a small part of the total phosphorus intake, especially during the low-fibre diet period. Between 24 and $61 \%$ (mean $\pm \mathrm{SE}, 41 \pm 4.3 \%$ ) of phytate-P from ingested bran was found in the ileostomy contents. There was no significant correlation between recovery of phytate-P in ileostomy fluid and that of $\mathrm{Zn}, \mathrm{Fe}, \mathrm{Mg}, \mathrm{Ca}$ and non-phytate- $\mathrm{P}$ during the low-fibre diet or bran period.

Apparent absorption of minerals. Intake, recoveries in ileostomy fluid and apparent 
absorption of minerals are given in Tables 1 and 2. In the bran period a significantly decreased amount of $\mathrm{Zn}$ was absorbed $(P<0.01)$ while that of phytate-P $(P<0.01)$ and $\mathrm{Fe}(P<0.02)$ increased. No significant difference in absolute absorption of non-phytate-P, $\mathrm{Ca}$ and $\mathrm{Mg}$ between the two periods was found. Due to the mineral content of bran the relative absorption differed in some respect from the absolute absorption. There was a significant decrease in relative absorption of $\mathrm{Zn}, \mathrm{Mg}$ and phytate-P after consumption of bran while that of $\mathrm{Ca}, \mathrm{Fe}$ and non-phytate-P did not differ significantly between the periods.

\section{DISCUSSION}

The transit time of the small intestine is short and consequently the difficulties in demarcating faeces in portions that correspond to the period of intake are avoided by studying ileostomy patients. The undigested bran components are excreted on the day of consumption, as reported earlier (Sandberg et al. 1981). Phytate is partly digested in the stomach and small intestine or possibly absorbed. Our results correspond well to that of McCance and Widdowson (1935), who found $20-60 \%$ of ingested phytin-P from wheat products in the faeces of normal subjects. The bacterial degradation in the colon thus seems less important. This is in agreement with studies on dogs which indicate that the degradation of phytate occurs chiefly in the first two-thirds of the small intestine and to a minor extent in the colon (Jenkins \& Philips, 1960).

It is a matter of discussion whether or not there is any difference between normal subjects and ileostomy patients concerning mineral absorption. It is likely that a slight absorption takes place in the colon but the principal absorption should occur in the small intestine The formation of mineral-organic complexes is highly pH-dependent.

The $\mathrm{pH}$ value of the ileostomy contents was not measured in the study but in other ileostomy patients we have found $\mathrm{pH}$ values between 6 and 8 corresponding to that of the ileum contents of normal subjects. Thus, in this respect ileostomy patients should not differ from normal subjects and the result would reflect the absorption in the human small intestine. In the present study the endogenous excretion of minerals was not measured and was supposed to be the same in both periods.

The amounts of absorbed $\mathrm{Mg}$ and non-phytate-P did not seem to be affected by the consumption of $16 \mathrm{~g}$ wheat bran. The absorption of Ca was slightly decreased in seven of the eight patients but not significantly. It appears as if phytate-P is almost as effectively utilized as non-phytate-P. Bran seems to decrease the absorption of $\mathrm{Zn}$. That the reduced absorption of $\mathrm{Zn}$ during period 2 was due to the bran intake is supported by the fact that the three patients studied during ten consecutive days showed an increase in $\mathrm{Zn}$ absorption during the last $3 \mathrm{~d}$ i.e. after the bran period. The reduced $\mathrm{Zn}$ absorption might be due to the formation of a $\mathrm{Zn}$-phytate complex; however, there was no correlation during the bran period between the daily excretion of phytate and $\mathrm{Zn}$ in ileostomy contents. It has been demonstrated that a dietary intake of phytate causes a depression in growth rate in young rats if the phytate: $\mathrm{Zn}$ molar ratios are large (Oberleas \& Prasad, 1976; Davies \& Olpin, 1979; Morris \& Ellis, $1980 a, b$ ). The effect on $\mathrm{Zn}$ absorption in humans of $2.5 \mathrm{~g}$ phytic acid added daily to the diet was studied by Reinhold, Nasr et al. (1973). Balance studies on subjects with intake of leavened or unleavened whole-meal bread were also performed (Reinhold, Hedayati et al. 1973). In both studies the conclusion drawn was that phytic acid decreases the availability and intestinal absorption of $\mathrm{Zn}$. The importance of phytic acid was later questioned by Reinhold et al. $(1976 a)$. This new view was supported by negative $\mathrm{Zn}$ balances observed in two subjects who had a high intake of whole-meal bread, with a moderate phytate content (Reinhold et al. 1976 b) and in vitro studies on the Zn-binding capability of various fibre fractions (Ismail-Beige et al. 1977). When comparing $\mathrm{Zn}$ availability to rats from diets supplemented with bran, bran fibre or phytate, Davies et al. 
(1977) concluded that phytate rather than fibre is the main determinant of Zn availability. The fibre content was not found to affect $\mathrm{Zn}$ balances in a $30 \mathrm{~d}$ study period during which $26 \mathrm{~g}$ of various fibres were added to a normal American diet (Sandstead et al. 1979). Bioavailability to rats of $\mathrm{Zn}$ in raw wheat bran and low-phytate brans containing almost the same amounts of neutral detergent fibre was investigated by Morris \& Ellis (1980 b). They found no evidence that the fibre of wheat bran diminished the bioavailability of $\mathrm{Zn}$ to rats. In a study on humans (B. Nävert, $\AA$. Cederblad and B. Sandström, unpublished results) bran-containing breads with low content of phytate, obtained by long leavening time $(15 \mathrm{~h})$, was compared with high-phytate breads made with short leavening time $(1 \mathrm{~h})$. The amount of dietary fibre was equal in both types of bread. The $\mathrm{Zn}$ absorption was approximately twice as high from the low-phytate bread. Most of the recent literature indicates an effect of phytate. The present study, however, does not determine whether phytate or some other component in bran is responsible for the reduced $\mathrm{Zn}$ absorption.

The apparent absorption of $\mathrm{Fe}$ was high in both periods. A diet rich in meat products should give good $\mathrm{Fe}$ and $\mathrm{Zn}$ absorption, but does not explain the very high $\mathrm{Fe}$ absorption found in some patients. The $\mathrm{Fe}$ status was assessed by measuring haemoglobin, serum-Fe and total iron binding capacity. These were within normal range, except for three patients, who had slightly lowered serum-Fe. Fe-deficiency anaemia frequently occurs in patients with ulcerative colitis before they are proctocolectomized but the high $\mathrm{Fe}$ absorption in some of the patients indicated low $\mathrm{Fe}$ stores 7 months- 2 years after the operation. The Fe status should, however, be the same in the two consecutive periods. In balance studies only apparent absorption is measured. A prolonged radio iron excretion has been demonstrated in normal subjects after oral intake, indicating a temporary mucosal uptake and storage of iron (Björn-Rasmussen et al. 1980). The apparent absorption might therefore be higher than the true absorption of iron.

The apparent absorption of $\mathrm{Fe}$ in absolute amounts increased when bran was consumed. More than $60 \%$ of the $\mathrm{Fe}$ in wheat bran is present in the form of monoferric phytate (Morris \& Ellis, 1976). Studies on rats (Ellis \& Morris 1979), dogs (Lipschitz et al. 1979) and humans (Simpson et al. 1981) demonstrate that $\mathrm{Fe}$ from monoferric phytate can be absorbed. Of great importance is the extent to which $\mathrm{Fe}$ is solubilized in the upper duodenum, where the main absorption takes place (Schulerud, 1980). Studies on anaemic rats (Schulerud, 1980) and pigs (Frölich \& Lysö, 1980) have shown that Fe from bran is utilized just as well as or even better than ferrous sulphate. In this respect our results conflict with those of Björn-Rasmussen (1974), Dobbs \& Baird (1977) and Simpson et al. (1981), who found a decrease in relative $\mathrm{Fe}$ absorption when a single meal with baked bread or muffins containing wheat bran or whole meal was compared with bread of low bran content, white bread or plain muffins. Simpson et al. (1981) held the Fe content constant by the addition of $\mathrm{FeCl}_{3}$, but in the studies of Björn-Rasmussen (1978) and Dobbs \& Baird (1977) there was no reduction of absorption when calculating in absolute amounts since bran is rich in Fe. Sandstead et al. (1979) found no effect of bran on Fe balances. In the studies on humans referred to, the bran was given in baked bread in which $\mathrm{Fe}$ might no longer be present as monoferric phytate. Ferric phytate with $2-4 \mathrm{~mol} \mathrm{Fe}$ has poor bioavailability, at least in the rat (Ellis \& Morris, 1979). Formation of such compounds may take place during baking. Another possible explanation is that a single meal test does not give the same results as a study of the total daily absorption as a reduced absorption from one meal might be compensated by another. The protein level in the meals may also be of importance.

It is concluded that phytate is partly digested in the stomach and small intestine or possibly absorbed. A supplement of $16 \mathrm{~g}$ wheat bran to the diet does not negatively affect the absorption of minerals from the small intestine, other than $\mathrm{Zn}$. 
This study was - supported by the Swedish Medical Council (project no. B80-17X-03117-10A) and the National Swedish Board for Technical Development (project no. 79-5226).

\section{REFERENCES}

Björn-Rasmussen, E. (1974). Nutr. Metab. 16, 101.

Björn-Rasmussen, E. (1978). Näringsforskning 22, 229.

Björn-Rasmussen, E., Carneskog, J. \& Cederblad, Å. (1980). Scand. J. Haematol. 25, 124.

Cummings, J. H. (1978). Am. J. clin. Nutr. 31, Suppl 21.

Davies, N. T. (1979). Dietary Fibre: Current Developments of Importance to Health, p. 113 [K. W. Heaton, editor]. Westport: Technomic Publishing Company.

Davies, N. T., Hristic, V. \& Flett, A. A. (1977). Nutr. Rep. int. 15, 207.

Davies, N. T. \& Olpin, S. E. (1979). Br. J. Nutr. 41, 591.

Dobbs, R. J. \& Baird, I. M. (1977). Br. med. J. i, 1641.

Ellis, R. \& Morris, E. R. (1979). Nutr. Rep. int. 20, 739.

Ellis, R., Morris, E. R. \& Philpot, C. (1977). Analyt. Biochem. 77, 536.

Fiske, C. M. \& Subbarow, Y. (1925). J. biol. Chem. 66, 375.

Frölich, W. \& Lysö, A. (1980). Näringsforskning 24, 67.

Isaksson, B. \& Sjögren, B. (1967). Proc. Nutr. Soc. 26, 106.

Ismail-Beige, F., Faraji, B. \& Reinhold, J. G. (1977). Am. J. clin. Nutr. 30, 1721

Jenkins, K. J. \& Philips, P. M. (1960). J. Nutr. 70, 235.

Lipschitz, D. A., Simpson, K. M., Cook, J. D. \& Morris, E. R. (1979). J. Nutr. 109, 154.

McCance, R. A. \& Widdowson, E. M. (1935). Biochem. J. 29, 2694.

McCance, R. A. \& Widdowson, E. M. (1942a). Lancet i, 588.

McCance, R. A. \& Widdowson, E. M. (1942b). J. Physiol., Lond. 101, 304.

Morris, E. R. \& Ellis, R. (1976). J. Nutr. 106, 753.

Morris, E. R. \& Ellis, R. (1980a). J. Nutr. 110, 1037.

Morris, E. R. \& Ellis, R. (1980b). J. Nutr. 110, 2000.

Oberleas, D. \& Prasad, A. S. (1976). Trace Elements in Human Health and Disease, vol 1, p. 156 [A. S. Prasad, editor]. New York: Academic Press.

Reinhold, J. G., Faradji, B., Abadi, P. \& Ismail-Beige, F. (1976a). Trace Elements in Human Health and Disease, vol. 1, p. 163 [A. S. Prasad, editor]. New York: Academic Press.

Reinhold, J. G., Faradji, B., Abadi, P. \& Ismail-Beige, F. (1976b). J. Nutr. 106, 493.

Reinhold, J. G., Hedayati, H., Lahimgarzadeh, A. \& Nasr, K. (1973). Ecol. Fd. Nutr. 2, 157.

Reinhold, J. G., Nasr., K., Lahimgarzadeh, A. \& Hedayati, H. (1973). Lancet i, 283.

Sandberg, A.-S., Andersson, H., Hallgren, B., Hasselblad, K., Isaksson, B. \& Hultén, L. (1981). Br. J. Nutr. 45, 283.

Sandstead, H. H., Klevay, L. M., Jacob, R. A., Munoz, J. M., Logan, G. M. Jr., Reck, S. J., Dintzis, F. R., Inglett, G. E. \& Shuey, W. C. (1979). Dietary Fibers: Chemistry and Nutrition, p. 147 [G. E. Inglett and S. I. Falkehag, editors]. New York: Academic Press.

Sandström, B. (1980). Zinc absorption from composite meals. PhD Thesis, University of Gothenburg.

Schulerud, A. (1980). Näringsforskning 24, 104.

Simpson, K. M., Morris, E. R. \& Cook, J. D. (1981). Am. J. clin. Nutr. 34, 1469. 